\title{
Aplikasi Analytical Hierarchy Process: Sistem Pendukung Keputusan untuk Seleksi Desa Inovasi di Wilayah Sorong
}

\section{(Application of the Analytical Hierarchy Process: Decision-Supporting System for Selection of Innovation Village in Sorong Region)}

\author{
Ismail, Muhamad Ali Ulat, Muhfizar, Mustasim, Hendra Poltak*
}

(Diterima Juli 2021/Disetujui Agustus 2021)

\begin{abstract}
ABSTRAK
Ketimpangan sosial desa-kota menjadi masalah yang harus diselesaikan untuk mencapai kesejahteraan dan keadilan ekonomi yang diidamkan oleh semua umat manusia. Upaya untuk mengatasi permasalahan ini dilakukan Program Desa Inovasi Kelautan dan Perikanan yang merupakan program pemberdayaan masyarakat kelautan dan perikanan untuk dapat memanfaatkan teknologi dan inovasi sebagai upaya meningkatkan kesejahteraan masyarakat. Anggaran dan sumber daya yang terbatas menyebabkan tidak semua desa yang menjadi mitra pengabdian masyarakat Politeknik Kelautan dan Perikanan Sorong dapat dijadikan Desa Inovasi Kelautan dan Perikanan. Penelitian ini dilakukan untuk menentukan prioritas ranking alternatif desa yang akan dipilih dan dilakukan intervensi inovasi dan teknologi sesuai dengan kriteria-kriteria yang telah ditentukan. Pengambilan keputusan desa inovasi kelautan dan perikanan ini membutuhkan suatu metode yang sistematis dan akurat dengan menggunakan Analytical Hierarchy Process (AHP). Pada studi kasus, seleksi Program Desa Inovasi dilakukan pada tiga lokasi yang berada di Wilayah Sorong (Desa Walal, Desa Rimbapala, dan Desa Pulau Raam). Kriteria yang digunakan dalam pemilihan alternatif desa inovasi ialah 1) memiliki dukungan pemerintah daerah, 2) respons masyarakat, 3) ada komoditas unggulan perikanan, 4) aksesibilitas, dan 5) sesuai dengan sumber daya yang dimiliki oleh Politeknik KP Sorong. Hasil yang diperoleh berdasarkan metode AHP diperoleh penilaian, yaitu Pulau Raam 58,7\%, Walal 21,9\%, dan Rimbapala 19,4\%. Kesimpulan adalah bahwa yang terpilih sebagai desa inovasi adalah Desa Pulau Raam dengan nilai $58,7 \%$ yang merupakan nilai tertinggi.
\end{abstract}

Kata kunci: alternatif, analytical hierachy process, desa Inovasi, kriteria, pilihan

\section{ABSTRACT}

Rural-urban social inequality is a problem that must be solved to achieve prosperity and economic justice that is desired by all human beings. Efforts to overcome the problem are to create and carry out the Program of Marine and Fisheries Innovation Village which is a program of marine and fisheries community empowerment to be able to take advantage of technology and innovation as an effort to improve their lives. Limited budget and resources cause not all villages that are partners in community service at the Sorong Marine and Fisheries Polytechnic can be turned into Marine and Fisheries Innovation Villages. This research was conducted to determine the priority ranking of villages to be selected and to carry out innovation and technology interventions according to the predetermined criteria. Decision making in this marine and fisheries innovation village requires a systematic and accurate method using the Analytical Hierarchy Process (AHP). In the case study, the selection of the innovation village program was carried out at three locations in the Sorong area (Walal Village, Rimbapala Village, and Pulau Raam Village). The criteria used in the selection of alternative innovation villages were: 1) having local government support, 2) community response, 3) having superior fishery commodities, 4) accessibility, and 5) in accordance with the resources owned by the KP Sorong Polytechnic. The results obtained based on the AHP method were Raam Island $58,7 \%$, Walal $21,9 \%$, and Rimbapala $19,4 \%$. The conclusion is that the village selected as the innovation village is Raam Island with the highest score of $58,7 \%$.

Keywords: alternatives, analytical hierarchy process, criteria, innovation village, options

\section{PENDAHULUAN}

Ketimpangan sosial antara desa-kota menjadi masalah yang harus diselesaikan untuk mencapai kesejahteraan dan keadilan ekonomi yang diidamkan

Politeknik Kelautan dan Perikanan Sorong, Jl. Kapitan Pattimura Tanjung Kasuari Suprau, Kota Sorong, Papua Barat, 98401

* Penulis Korespondensi:

E-mail: hendra.poltak@polikpsorong.ac.id oleh semua umat manusia (Bapna 2012; Griggs et al. 2013; Imai \& You 2014; Tollefson 2015). Ketimpangan sosial identik dengan keterbatasan mengakses sumber daya dan optimalisasi sumber daya manusia. Kondisi ini banyak terjadi di wilayah perdesaan, berbeda dari wilayah perkotaan yang memiliki kemudahan dan keragaman akses sumber daya dan optimalisasi sumber daya manusia. Keterbatasan ini mengakibatkan kemiskinan, yang umumnya banyak dilekatkan pada masyarakat desa (Todaro \& Smith 2011) dan 
termasuk juga wilayah pesisir yang merupakan wilayah kategori termiskin dalam strata sosial ekonomi di Indonesia (Anwar \& Wahyuni 2019).

Upaya yang dilakukan untuk mengatasi permasalahan di atas adalah dengan pemberdayaan masyarakat melalui program desa inovasi. Program yang mampu menggali maupun mengubah potensi suatu wilayah menjadi kekuatan ekonomi dan mempersempit jurang kesenjangan adalah melalui intervensi sains dan inovasi ke dalam suatu desa sehingga membantu masyarakat desa meningkatkan perekonomiannya (Darwis \& Rusastra 2016; Rahadi 2016). Kementerian Desa, Pembangunan Daerah Tertinggal, dan Transmigrasi pertama sekali menginisiasi program ini, selanjutnya diikuti oleh Kementerian/Lembaga termasuk Kementerian Kelautan dan Perikanan melalui Program Desa Inovasi Kelautan dan Perikanan yang melakukan pember-dayaan komunitas kelautan dan perikanan untuk memanfaatkan teknologi dan inovasi dalam memperbaiki kehidupan dan kesejahteraan masyarakat.

Program desa inovasi yang berhasil adalah program yang mampu mensinergikan antara kekuatan internal dan kekuatan eksternal. Kekuatan internal yang dimaksud di sini adalah potensi desa yang akan dikembangkan berupa komoditas serta sumber daya manusia dan kekuatan eksternal adalah intervensi ilmu pengetahuan dan teknologi yang mudah diterima oleh masyarakat.

Keterbatasan anggaran dan sumber daya menyebabkan tidak semua desa dapat diintervensi menjadi desa inovasi. Pemilihan desa yang tepat yang mampu mensinergikan kekuatan internal dan eksternal perlu dilakukan dengan optimal. Pemilihan desa inovasi yang tepat melalui keputusan yang objektif sesuai dengan kriteria dapat dilakuan melalui teknik Analytical Hierachy Process (AHP).

Pengambilan keputusan multikriteria yang digunakan oleh Baffoe (2019) bertujuan untuk mengeksplorasi AHP dalam intervensi pembangunan perdesaan yang efektif. Penggunaan AHP menghasilkan manfaat sosial yang tinggi, mengefisienkan anggaran, dan kepastian keberlanjutan kegiatan. Penerapan AHP yang dilakukan dalam pengalokasian dana desa di Desa Suka, Kecamatan Tiga Panah, Kabupaten Karo oleh Yogi (2019) menghasilkan urutan kepentingan prioritas dana desa yang akan dialokasikan. Perbedaan penelitian ini dari penelitian Rahayu et al. (2019) adalah bahwa penelitian sebelumnya (Rahayu et al., 2019) merupakan evaluasi atas desa terbaik, sedangkan penelitian ini merupakan perencanaan pemilihan desa inovasi. Choi (2015) menggunakan metode AHP untuk memfasilitasi keputusan pelaksanaan program pembangunan perdesaan yang lebih akurat sesuai dengan kebutuhan masyarakat.

Penelitian ini dilakukan dengan membangun 5 kriteria sesuai dengan Peraturan KaBRSDM No. 6 (2020), yaitu: 1) memiliki dukungan pemerintah daerah, 2) adanya respons masyarakat, 3) adanya komoditas dan unit usaha, 4) adanya aksesibilitas, dan
5) sesuai dengan sumber daya yang dimiliki oleh Politeknik Kelautan dan Perikanan Sorong. Penelitian ini bertujuan untuk pemilihan prioritas desa untuk dilakukan intervensi berupa inovasi dan teknologi oleh Politeknik Kelautan dan Perikanan Sorong.

\section{METODE PENELITIAN}

Penelitian ini merupakan penelitian deskriptif untuk menggambarkan realitas objek yang diteliti secara objektif. Metode pengumpulan data dilakukan dengan survei lokasi, observasi, dan wawancara yang terkait dengan kriteria karakteristik desa dan masyarakat desa, dan mencari literatur yang menunjang penelitian. Objek penelitian adalah tiga desa yang bercirikan kelautan dan perikanan yang menjadi tempat pengabdian masyarakat Politeknik Kelautan dan Perikanan Sorong. Hasil pengumpulan data menjadi matriks perbandingan yang diisi oleh responden ahli yang memahami dan memiliki pengalaman pada kawasan calon desa inovasi. Responden ahli merupakan dosen dengan masa kerja lebih dari 10 tahun dan minimal memiliki jabatan akademik lektor. Jumlah repsonden terpilih adalah sebanyak enam orang.

Tahapan inti untuk menentukan desa inovasi adalah dilakukan analisis data dengan metode matematika yang sederhana (Ramírez-Rivera et al. 2020) dan menakjubkan untuk mendapat hasil akhir melalui AHP (Cooper 2017). Prosedur Analytical Hierarchy Process dilakukan sebagai berikut (Kusrini 2007):

- AHP menyusun multikriteria secara hierarki yang diawali dengan penetapan tujuan pada level teratas, diikuti dengan penentuan kriteria dan subkriteria pada level menengah, serta mempertimbangkan alternatif-alternatif pada level terendah. Hierarki yang sudah disusun disajikan pada Gambar 1.

- Menentukan Prioritas Kriteria Penilaian Desa Inovasi dengan perbandingan berpasangan.

Melakukan perbandingan berpasangan (pairwaise comparison) bertujuan untuk menentukan prioritas setiap elemen dengan elemen lainnya pada level kriteria maupun level alternatif, maupun pasangan alternatif untuk setiap kriteria (Benítez et al. 2015). Bobot penilaian dikuantitatifkan dengan menggunakan skala nominal 1 sampai dengan 9 yang maknanya dapat dilihat pada Tabel 1.

- Menguji Konsistensi

Uji konsistensi menggunakan Rasio Konsistensi (Consistence Ratio) dihitung dengan rumus:

$$
\mathrm{CR}=\mathrm{CI} / \mathrm{IR}
$$

Dengan $\mathrm{Cl}=$ Indeks Konsistensi (Consistence Index), IR = Indeks Random (Random Index)

Jika $C R<0,1$, maka hierarki konsisten dapat diterima

$$
\mathrm{CI}=\left(\gamma_{\max }-\mathrm{n}\right) /(\mathrm{n}-1)
$$

Random Index (RI) diperoleh berdasarkan Tabel 2. - Pengambilan Keputusan 


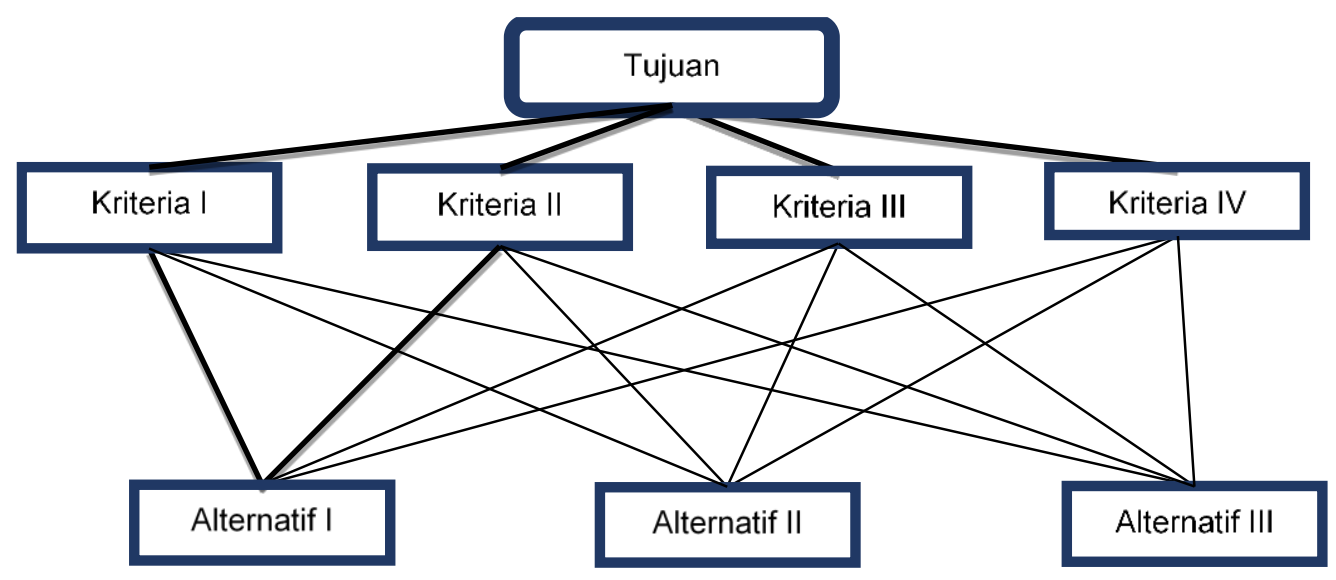

Gambar 1 Struktur AHP

Tabel 1 Skala preferensi AHP

\begin{tabular}{cl}
\hline Skala AHP & \multicolumn{1}{c}{ Keterangan } \\
\hline 1 & Kedua elemen sama pentingnya \\
3 & Elemen yang satu sedikit lebih penting daripada elemen yang lainnya \\
5 & Elemen yang satu lebih penting daripada elemen yang lainnya \\
7 & Elemen yang satu sangat penting daripada elemen yang lainnya \\
9 & Satu elemen mutlak sangat penting daripada elemen lainnya \\
$2,4,6,8$ & Nilai-nilai antara dua nilai pertimbangan yang berdekatan \\
Berbalikan & Jika untuk aktivitas i mendapat satu angka dibanding dengan aktivitas j, maka j memiliki nilai kebalikannya \\
& dibanding dengan i \\
\hline
\end{tabular}

Tabel 2 Random konsistensi indeks

\begin{tabular}{cccccc}
\hline 1 & 2 & 3 & 4 & 5 & 6 \\
\hline 0,00 & 0,00 & 0,58 & 0,90 & 1,12 & 1,24 \\
\hline
\end{tabular}

Keputusan diambil berdasarkan peringkat tertinggi perpaduan kriteria terhadap alternatif.

\section{HASIL DAN PEMBAHASAN}

Desa yang memiliki potensi dan dapat mengoptimalkan potensi yang ada memiliki potensi untuk dipilih menjadi desa inovasi (Darmoko 2015). Optimalisasi potensi ini dapat dilakukan sendiri maupun melalui intervensi oleh pihak luar. Keberhasilan menjadi desa inovasi dapat diintervensi menggunakan kriteriakriteria, di antaranya:

- Dukungan pemerintah daerah: kriteria ini merupakan faktor yang dapat mendukung kelancaran proses pemberdayaan masyarakat (Sugiri 2012). Dukungan berupa peran pemerintah menggali potensi masyarakatnya, merangsang, dan memberi motivasi sehingga masyarakat berdaya dan mandiri.

- Respons masyarakat merupakan partisipasi atas keikutsertaan dalam aktivitas mulai dari awal sampai akhir (Arifiani \& Sjaf 2018). Respons masyarakat yang positif akan memudahkan intervensi ilmu pengetahuan dan teknologi.

- Komoditas dan unit usaha sumber daya alam yang dapat diolah dan diperdagangkan dan menjadi kegiatan usaha yang berkesinambungan. Identifi- kasi komoditas dan unit usaha merupakan pendekatan pelaksanaan desa inovasi.

- Aksesibilitas yang merupakan kombinasi moda transportasi untuk mencapai lokasi tujuan (Geurs et al. 2009), yang diukur dengan biaya, jarak, dan waktu (Ortega et al. 2014). Aksesibilitas juga merupakan ketersediaan fasilitas pendukung berupa transportasi dan komunikasi. Aksesibilitas yang baik memudahkan diseminasi ilmu pengetahuan dan teknologi ke desa inovasi serta memudahkan hasil produksi untuk dapat dipasarkan.

- Sumber daya Politeknik KP Sorong merupakan sinergi kekuatan internal di wilayah desa inovasi dengan kekuatan eksternal tim intervensi inovasi. Kekuatan eksternal ini berupa adanya program studi yang dapat memberikan pelayanan berupa pelatihan, penyuluhan, agen alih teknologi, dan pusat kajian yang sesuai dengan kawasan yang akan diintervensi.

Alternatif pilihan desa untuk dijadikan sebagai desa inovasi berjumlah tiga desa. Dua kawasan desa berada di wilayah Kota Sorong dan satu wilayah berada di Kabupaten Sorong. Gambar 2 menunjukkan peta wilayah alternatif desa inovasi.

Gambaran ringkas masing-masing desa berdasarkan kriteria yang telah ditentukan adalah sebagai berikut: 


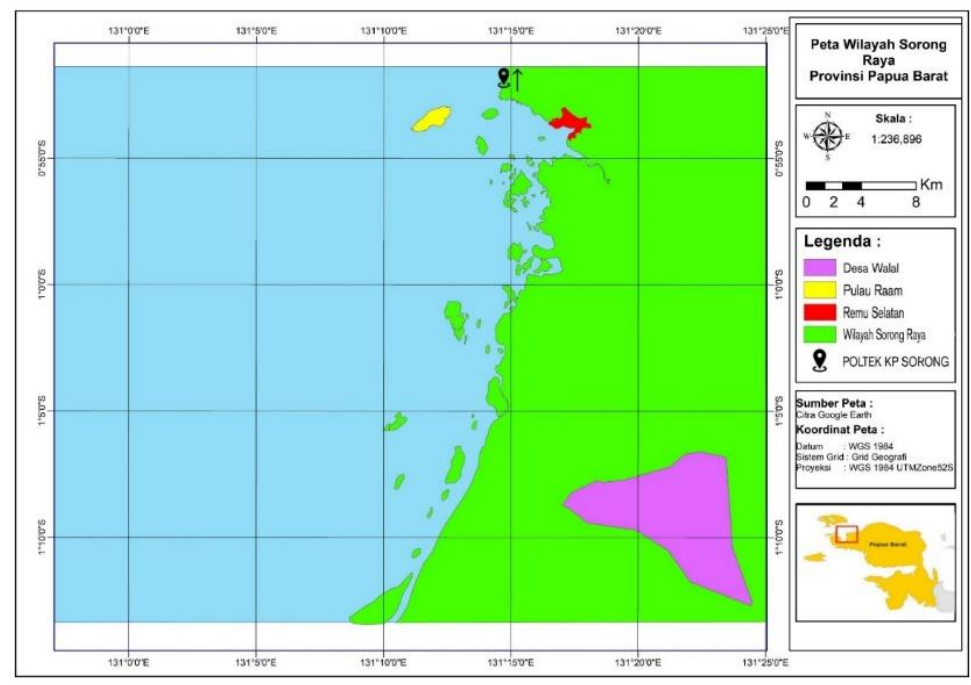

Gambar 2 Peta wilayah alternatif desa inovasi A) Rimbapala (merah), B) Pulau Raam (kuning), dan C) Walal (merah jambu)

\section{- Rimbapala}

Luas wilayah adalah $0,094 \mathrm{~km}^{2}$ dengan jumlah kepala keluarga 178 kk. Kawasan ini berada di Kelurahan Remu Selatan, Distrik Sorong Manoi, Kota Sorong. Rimbapala merupakan kawasan yang berada di tengah Kota Sorong. Pemerintah melakukan pemberdayaan di lokasi ini dengan meningkatkan akses infrastruktur permukiman yang layak. Penduduk sebagian besar merupakan nelayan kepiting yang menangkap kepiting di wilayah mangrove di sekitar maupun di wilayah Kabupaten Sorong dan Rajaampat. Hasil tangkapan dijual ke pengumpul dan dipasarkan sendiri. Rimbapala dapat dijangkau dengan kendaraan bermotor sekitar 20 menit.

- Pulau Raam

Luas wilayah adalah $0,5 \mathrm{~km}^{2}$ dengan jumlah kepala keluarga 240 kk. Kawasan ini berada di Kelurahan Pulau Raam, Distrik Sorong Kepulauan, Kota Sorong. Pulau Raam lebih dikenal dengan sebutan pulau buaya karena kontur pulau mirip buaya ditinjau dari kejauhan. Sesuai dengan letak geografisnya, sebagian besar penduduk merupakan nelayan tradisional yang melakukan penangkapan berbagai jenis ikan, terutama ikan tuna. Pulau Raam dapat dijangkau dengan menggunakan perahu mesin sekitar 10 menit.
- Walal

Luas wilayah adalah $70,92 \mathrm{~km}^{2}$ dengan jumlah kepala keluarga $238 \mathrm{kk}$. Kawasan ini merupakan bagian dari Distrik Salawati, Kabupaten Sorong. Dana desa di desa ini dikelola dengan baik sehingga memberikan kemandirian dan keberdayaan Kampung Walal. Hasil produksi budi daya skala kecil berupa ikan Nila dipasarkan secara langsung ke pasar. Wilayah ini dapat dijangkau sekitar 60 menit.

Berdasarkan informasi yang diperoleh melalui survei lokasi, wawancara, dan studi literatur maka disarikan menjadi data yang diserahkan kepada enam pakar yang telah dipilih untuk dianalisis. Expert menilai kuesioner yang diberikan berdasarkan data yang diperoleh dan pengalamannya menggunakan perbandingan berpasangan (Saaty 2008), hasilnya diolah dengan langkah-langkah sebagai berikut:

- Penyusunan Hierarki Kriteria untuk menentukan desa inovasi (Gambar 3)

- Menentukan Prioritas Kriteria Pemilihan Desa Inovasi dengan matriks perbandingan berpasangan Perhitungan perbandingan berpasangan kriteria nilainya diambil dari tim penilai. Keenam nilai yang telah diisi oleh expert dilakukan geometrik mean sehingga nilai yang dimasukkan adalah hasil dari

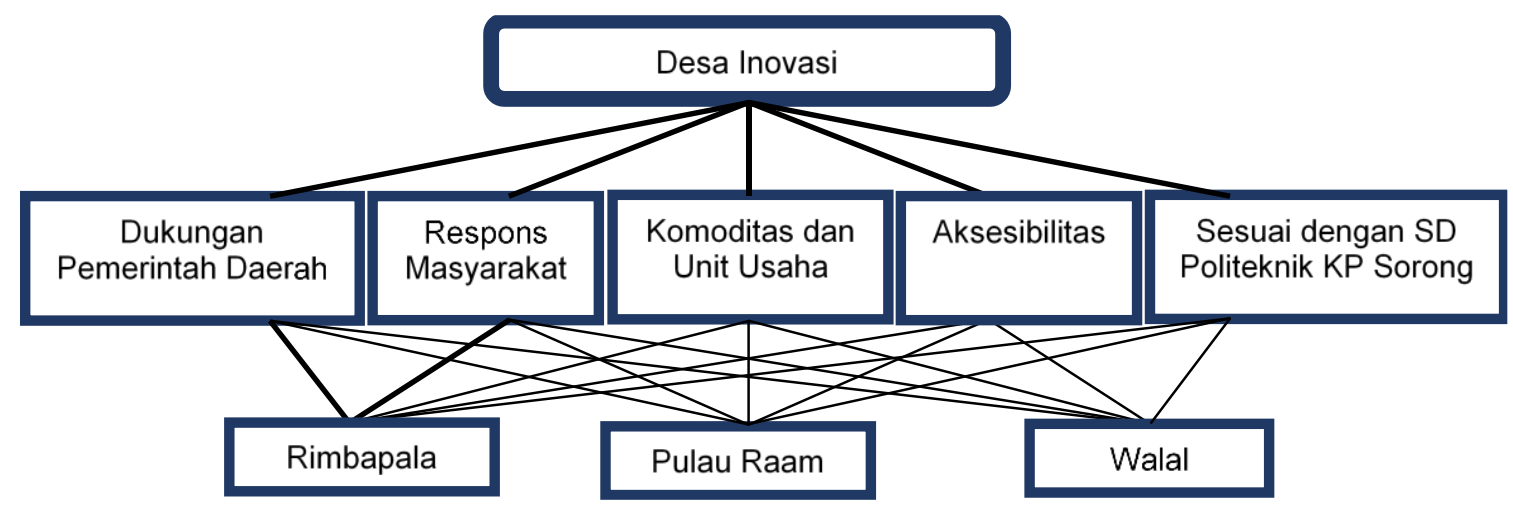

Gambar 3 Struktur AHP pemilihan desa inovasi 
geometrik mean. Berikut matriks perbandingan disajikan pada Tabel 3.

Matriks perbandingan berpasangan kriteria yang telah disusun dilakukan normalisasi dengan mencari nilai Eigen. Matriks normalisasi kriteria diperoleh pada Tabel 4.

Penjumlahan matriks normalisasi menunjukkan angka 1 yang mengindikasikan perhitungan yang dilakukan telah sesuai.

Nilai rata-rata kriteria merupakan prioritas kriteria yang paling berpengaruh pada tujuan pemilihan desa inovasi. Rata-rata kriteria diperoleh dengan membagi keseluruhan nilai Eigen kriteria dengan jumlah elemen kriteria. Nilai prioritas masingmasing kriteria diperoleh sesuai dengan Tabel 5.

Prioritas kriteria yang sudah didapat harus diuji untuk memastikan bahwa kriteria yang digunakan dalam metode AHP konsisten. Konsistensi kriteria menentukan kelanjutan perhitungan.

- Uji Konsistensi

- Menghitung Lamda maksimum dengan menjumlahkan jumlah kolom kriteria dikali dengan rata-rata baris kriteria. Perhitungan lamda maksimum adalah sebagai berikut:

$=(6,682 \times 0,154)+(3,235 \times 0,290)+(3,194 \times$ $0,339)+(10,579 \times 0,101)+(8,643 \times 0,115)$

$=1,028+0,938+1,084+1,173+0,997$

$=5,120$

Lambda maksimum $=5,120$

- Menghitung konsistensi indeks (Cl), matriks berordo 5 sebagai berikut:

$$
\begin{aligned}
\mathrm{CI} & =(5,120-5) /(5-1) \\
& =(0,120) / 4 \\
& =0,030
\end{aligned}
$$

- Menghitung rasio konsistensi

IR adalah indeks random dengan nilai 1,12 karena pada kasus ini mempunyai ukuran matriks berordo 5

$$
\begin{aligned}
\mathrm{CR} & =\mathrm{CI} / \mathrm{IR} \\
& =0,030 / 1,12 \\
& =0,027
\end{aligned}
$$

Nilai rasio konsistensi yang diperoleh adalah $0,027 \leq 1$ maka matriks memenuhi syarat konsistensi.

Ranking kriteria yang telah diuji konsisten dan layak digunakan sebagai kriteria dalam pemilihan desa inovasi. Bobot kriteria paling prioritas dalam pemilihan desa inovasi adalah komoditas dan unit usaha, yang tercantum pada Tabel 6 .

Penghitungan matriks perbandingan alternatif terhadap kriteria dilakukan untuk mendapatkan alternatif prioritas dari kriteria yang ada. Perhitungannya tidak berbeda dari perhitungan matriks perbandingan kriteria. Hasil perhitungan perbandingan alternatif terhadap kriteria disajikan pada Tabel 7.

- Pengambilan Keputusan

Perankingan alternatif merupakan langkah akhir dari metode AHP.

Perankingan alternatif diperoleh dengan cara mengalikan nilai Eigen dari masing-masing alternatif dengan nilai Eigen kriteria atau prioritas kriteria. Urutan presentase untuk pilihan desa Inovasi Kelautan dan Perikanan dapat dilihat pada Tabel 8.

Jumlah keseluruhan kriteria-kriteria yang telah ditentukan akan menghasilkan alternatif pilihan prioritas. Bobot tertinggi menjadi pilihan pertama. Berdasarkan data pada Tabel 8 maka urutan alternatif pilihan

Tabel 3 Matriks perbandingan berpasangan kriteria

\begin{tabular}{lccccc}
\hline \multicolumn{1}{c}{ Kriteria } & $\begin{array}{c}\text { Dukungan } \\
\text { pemerintah daerah }\end{array}$ & $\begin{array}{c}\text { Respons } \\
\text { masyarakat }\end{array}$ & $\begin{array}{c}\text { Komoditas } \\
\text { dan unit usaha }\end{array}$ & Aksesibilitas & $\begin{array}{c}\text { Sesuai dengan SD } \\
\text { Politeknik KP Sorong }\end{array}$ \\
\hline $\begin{array}{l}\text { Dukungan pemerintah } \\
\text { daerah }\end{array}$ & 1,000 & 0,550 & 0,405 & 2,080 & 1,089 \\
Respons masyarakat & 1,817 & 1,000 & 1,238 & 2,608 & 2,027 \\
Komoditas dan unit usaha & 2,466 & 0,808 & 1,000 & 4,096 & 3,267 \\
Aksesibilitas & 0,481 & 0,383 & 0,244 & 1,000 & 1,932 \\
Sesuai dengan SD & 0,918 & 0,493 & 0,306 & 0,518 & 1,000 \\
Politeknik KP Sorong & 6,682 & 3,235 & 3,194 & 10,303 & 9,315 \\
Jumlah & & & & & \\
\hline
\end{tabular}

Tabel 4 Matriks normalisasi kriteria

\begin{tabular}{lccccc}
\hline \multicolumn{1}{c}{ Kriteria } & $\begin{array}{c}\text { Dukungan } \\
\text { Pemerintah Daerah }\end{array}$ & $\begin{array}{c}\text { Respons } \\
\text { Masyarakat }\end{array}$ & $\begin{array}{c}\text { Komoditas dan } \\
\text { Unit Usaha }\end{array}$ & Aksesibilitas & $\begin{array}{c}\text { Sesuai dengan SD } \\
\text { Politeknik KP Sorong }\end{array}$ \\
\hline $\begin{array}{lcccc}\text { Dukungan Pemerintah } \\
\text { Daerah }\end{array}$ & 0,150 & 0,170 & 0,127 & 0,202 & 0,117 \\
Respons Masyarakat & 0,272 & 0,309 & 0,388 & 0,253 & 0,218 \\
Komoditas dan Unit & 0,369 & 0,250 & 0,313 & 0,398 & 0,351 \\
Usaha & 0,072 & 0,119 & 0,076 & 0,097 & 0,207 \\
Aksesibilitas & 0,137 & 0,152 & 0,096 & 0,050 & 0,107 \\
Sesuai dengan SD & 1,000 & 1,000 & 1,000 & 1,000 & 1,000 \\
Politeknik KP Sorong & & & \\
Jumlah & & &
\end{tabular}


Tabel 5 Prioritas kriteria

\begin{tabular}{lc}
\hline \multicolumn{1}{c}{ Kriteria } & Bobot \\
\hline Dukungan pemerintah daerah & 0,154 \\
Respons masyarakat & 0,290 \\
Komoditas dan unit usaha & 0,339 \\
Aksesibilitas & 0,101 \\
Sesuai dengan SD Politeknik KP Sorong & 0,115 \\
\hline
\end{tabular}

Tabel 6 Bobot kriteria desa inovasi

\begin{tabular}{lcc}
\hline \multicolumn{1}{c}{ Kriteria } & Bobot & Persentase \\
\hline Dukungan pemerintah daerah & 0,154 & 15,400 \\
Respons masyarakat & 0,290 & 29,000 \\
Komoditas dan unit usaha & 0,339 & 33,900 \\
Aksesibilitas & 0,101 & 10,100 \\
Sesuai dengan SD Politeknik KP & 0,115 & 11,500 \\
Sorong &
\end{tabular}

prioritas desa inovasi secara berturut adalah Pulau Raam sebagai prioritas pertama dengan nilai $58,7 \%$, prioritas kedua adalah Desa Walal dengan nilai $21,9 \%$, dan prioritas ketiga adalah Rimbapala dengan nilai $19,4 \%$. Dengan demikian, Pulau Raam mendapat prioritas tertinggi untuk dapat dilakukan intervensi teknologi dan inovasi untuk meningkatkan kesejahteraan melalui program desa inovasi.

\section{KESIMPULAN}

Berdasarkan hasil penelitian menggunakan metode Analitical Hierakhi Process (AHP) dan pembahasan, dapat disimpulkan hasil analisis responden ahli bahwa bobot kriteria desa inovasi kelautan dan perikanan secara berturut-turut dari prioritas tertinggi ke rendah adalah komoditas dan unit usaha $(33,9 \%)$, respons masyarakat $29,9 \%$ ), dukungan pemerintah $(15,4 \%)$, sesuai dengan sumber daya Politeknik Kelautan dan Perikanan Sorong $(11,5 \%)$, dan aksesibilitas $(10,1 \%)$.

Desa yang tepat sesuai dengan kriteria yang ditetapkan untuk dilakukan intervensi inovasi dan teknologi melalui desa inovasi adalah Pulau Raam dengan nilai tertinggi $58,7 \%$ dibandingkan dengan desa Walal $21,9 \%$ dan desa Rimbapala 19,4\%.
Pemilihan menggunakan kriteria dan objektif akan meningkatkan keberhasilan program.

\section{DAFTAR PUSTAKA}

Anwar Z, Wahyuni W. 2019. Miskin di laut yang kaya: nelayan Indonesia dan kemiskinan. Sosioreligius. 4(1).

Arifiani TA, Sjaf S. 2018. Analisis respon masyarakat terhadap pengelolaan dana desa untuk pembangunan pedesaan. Jurnal Sains Komunikasi dan Pengembangan Masyarakat. 2(3): 317-332. https://doi.org/10.29244/jskpm.2.3.31733 2

Baffoe G. 2019. Exploring the utility of analytic hierarchy process (AHP) in ranking livelihood activities for effective and sustainable rural development interventions in developing countries. Evaluation and Program Planning. 72: 197-204. https://doi.org/10.1016/j.evalprogplan.2018.10.017

Bapna M. 2012. Sustainability is key to development goals. Nature. 489(7416): 367. https://doi.org/10.10 $38 / 489367 a$

Benítez J, Delgado-Galván X, Izquierdo J, PérezGarcía R. (2015). Consistent completion of incomplete judgments in decision making using AHP. Journal of Computational and Applied Mathematics. 290: 412-422. https://doi.org/10.1016 j.cam.2015.05.023

Choi JS. 2015. Improvements of efficiency of analytical hierarchy process (AHP) for project priority in International Rural Development. 한국국제농업개 발학회/지. 27(1): 7-14. https://doi.org/10.12719/KSI A.2015.27.1.7

Cooper O. 2017. The magic of the analytic hierarchy process (AHP). International Journal of the Analytic Hierarchy Process. 9(3). https://doi.org/10.13033/ija hp.v9i3.519

Tabel 7 Nilai prioritas hasil perhitungan dari perbandingan alternatif terhadap kriteria

\begin{tabular}{lccccc}
\hline \multicolumn{1}{c}{ Kriteria } & $\begin{array}{c}\text { Dukungan } \\
\text { Pemerintah Daerah }\end{array}$ & $\begin{array}{c}\text { Respons } \\
\text { Masyarakat }\end{array}$ & $\begin{array}{c}\text { Komoditas dan } \\
\text { Unit Usaha }\end{array}$ & Aksesibilitas & $\begin{array}{c}\text { Sesuai dengan SD } \\
\text { Politeknik KP Sorong }\end{array}$ \\
\hline Rimbapala & 0,096 & 0,286 & 0,147 & 0,265 & 0,174 \\
Pulau Raam & 0,659 & 0,416 & 0,676 & 0,559 & 0,683 \\
Desa Walal & 0,246 & 0,298 & 0,177 & 0,176 & 0,143 \\
Jumlah & 1,000 & 1,000 & 1,000 & 1,000 & 1,000 \\
\hline
\end{tabular}

Tabel 8 Perhitungan row average tiap kriteria dengan row average antarkriteria

\begin{tabular}{lcccccc}
\hline & $\begin{array}{c}\text { Dukungan } \\
\text { Pemerintah Daerah }\end{array}$ & $\begin{array}{c}\text { Respons } \\
\text { Masyarakat }\end{array}$ & $\begin{array}{c}\text { Komoditas dan } \\
\text { Unit Usaha }\end{array}$ & Aksesibilitas & $\begin{array}{c}\text { Sesuai dengan SD } \\
\text { Politenik KP Sorong }\end{array}$ & Jumlah \\
\hline Rimbapala & 0,015 & 0,083 & 0,050 & 0,027 & 0,020 & 0,194 \\
Pulau Raam & 0,101 & 0,120 & 0,229 & 0,056 & 0,078 & 0,587 \\
Walal & 0,037 & 0,086 & 0,060 & 0,018 & 0,016 & 0,219 \\
\hline
\end{tabular}


Darmoko PD. 2015. Laporan penelitian potensi desa inovasi di Kabupaten Pemalang. Madaniyah. 5(2): 198-211.

Darwis V, Rusastra IW. 2016. Optimalisasi pemberdayaan masyarakat desa melalui sinergi program puap dengan desa mandiri pangan. Analisis Kebijakan Pertanian. 9(2): 125-142. https ://doi.org/10.21082/akp.v9n2.2011.125-142

Geurs KT, Boon W, Van Wee B. 2009. Social impacts of transport: literature review and the state of the practice of transport appraisal in the Netherlands and the United Kingdom. Transport Reviews. 29(1): 69-90. https://doi.org/10.1080/0144164080213049 0

Griggs D, Stafford-Smith M, Gaffney O, Rockström J, Öhman MC, Shyamsundar P, Steffen W, Glaser G, Kanie N, Noble I. 2013. Sustainable development goals for people and planet. Nature. 495(7441): 305-307. https://doi.org/10.1038/495305a

Imai KS, You J. 2014. Poverty dynamics of households in rural China. Oxford Bulletin of Economics and Statistics. 76(6): 898-923. https://doi.org/10.1111/o bes. 12044

Kusrini K. 2007. Aplikasi Sistem Pendukung Keputusan. Yogyakarta (ID): Andi.

Ortega E, López E, Monzón A. 2014. Territorial cohesion impacts of high-speed rail under different zoning systems. Journal of Transport Geography. 34: 16-24. https://doi.org/10.1016/j.jtrangeo.2013.1 0.018

Peraturan Kepala Badan Riset dan SDM Kelautan dan Perikanan Nomor 6/Per-BRSDM/2020, 64717173 1. 2020.
Rahadi DR. 2016. Model Pengembangan Kampung sebagai Desa Inovatif (Studi Kasus Kota Palembang). FIRM Journal of Management Studies. 1(2).

Rahayu T, Krisnanik E, Hananto B. 2019. Metode Analytical Hierarchy Process Dalam Menentukan Pemilihan Desa Terbaik. Jurnal Rekayasa Sistem Dan Teknologi Informasi. 3(1): 94-99. https://doi .org/10.29207/resti.v3i1.769

Ramírez-Rivera E de J, Morales-Carrera UA, LimónRivera R, Castillo-Martínez SI, Hernández-Salinas G, Ramírez-Sucre MO, Herrera-Corredor JA. 2020. Analytic hierarchy process as an alternative for the selection of vocabularies for sensory characterization and consumer preference. Journal of Sensory Studies. 35(1): e12547. https://doi.org /10.1111/joss. 12547

Saaty TL. 2008. Decision making with the analytic hierarchy process. International Journal of Services Sciences. 1(1): 83-98. https://doi.org/10.1504/IJSS Cl.2008.017590

Sugiri L. 2012. Peranan Pemerintah Daerah dalam Pemberdayaan Masyarakat. Publica. 2(1).

Todaro MP, Smith SC. 2011. Pembangunan Ekonomi. Jilid 1 Edisi 10. Jakarta (ID): Erlangga.

Tollefson J. 2015. Can randomized trials eliminate global poverty? Nature News. 524(7564): 150. https://doi.org/10.1038/524150a

Yogi M. 2019. Penerapan analytical hierarchy process dalam pengalokasian dana Desa Kecamatan Tiga Panah Kabupaten Karo. [Skripsi]. Medan (ID): Universitas Sumatera Utara. 